This is the version of the article accepted for publication in New Political Economy published by Taylor \& Francis: http://www.tandfonline.com/doi/full/10.1080/13563467.2017.1259304

Accepted version downloaded from SOAS Research Online: http://eprints.soas.ac.uk/23290/

\title{
Introduction to Special Issue on the Material Cultures of Financialisation ${ }^{1}$
}

\section{$\underline{\text { Introduction }}$}

\author{
Kate Bayliss, SOAS University of London \\ Ben Fine, SOAS University of London \\ Mary Robertson, University of Greenwich
}

This paper offers a wide-ranging introduction to the symposium on the material culture of financialisation. This collection of papers provides a number of detailed examples of the diverse ways in which finance and financialisation have become absorbed into many aspects of everyday life and the way in which material cultures have adapted so that this has become increasingly normalised. Each of material culture (cultural political economy) and financialisation has now attracted extensive literatures, incorporating equally diverse sets of conceptualisations that have mixed relations to one another and to their objects of enquiry. Our approach sets out its own framings in dealing with financialisation itself and its relationships to economic and social reproduction, including material culture. These framings may appear to be arbitrary but each has its own logic relative to its subject matter and to one another, as well as in traversing the connections between financialisation and material culture. Like others, we seek to escape simple dichotomies in which finance is perceived to be either real or imagined (fictitious) by forging links in the context of finance between material practices and their associated meanings (Haiven 2014).

Our approach draws upon the system of provision, SoP, approach (Fine 2002 and 2103). It conceives the economy as dependent upon distinct but overlapping SoPs, most obviously attached but not confined to different sectors of commodity production (for consumption). These SoPs interact with the material cultures that shape norms, values, meanings and practices associated with provisioning. We characterise these material cultures in terms of a number of core features which has been termed the 10Cs - that these cultures are Constructed, Construed, Conforming, Commodified, Contextual, Contradictory, Closed, Contested, Collective and Chaotic. The 10Cs are designed to capture or to bridge both the 
This is the version of the article accepted for publication in New Political Economy published by Taylor \& Francis: http://www.tandfonline.com/doi/full/10.1080/13563467.2017.1259304

Accepted version downloaded from SOAS Research Online: http://eprints.soas.ac.uk/23290/

complex nature of material cultures (the natures and contents of meanings) and the way in which they are forged through material and social processes. This general framing of material cultures attached to the economy by means of the SoP approach and the 10Cs is applied more specifically in case of financialisation in light of its being taken as a defining feature of contemporary, neoliberal capitalism and, correspondingly, a decisive factor in the restructuring and shaping of many if not all SoPs and their material cultures, as the papers in this volume testify.

However, not all provisioning takes the pure or ideal form of financialised commodity production and not all monetary relations are financialised, contingent upon how this is defined. Not only are there longstanding and increasingly complex cascades of monetary forms and practices (Jessop 2015) but these are also attached to equally diverse sets of economic practices and cultures (Dodd 2016), and theories of money (Lawson 2016). ${ }^{2}$ Accordingly, Section 2 begins by addressing the nature of financialisation itself, drawing on a tight definition drawn from Marxist political economy and attaching it to the accumulation of interest bearing capital. This is in order to distinguish financialisation as such from its diverse and wide-ranging effects and its looser associations within much of the literature with attachment to some sort of amorphous presence of credit or even simply (more extensive) monetary relations or ethos. These differences between financialisation and broader monetary relations within economic and social reproduction, of which material culture is a part, are addressed in Section 3 by drawing distinctions that prevail irrespective of financialisation as such, across commodification, commodity form and commodity calculation, ccfcc. These three are present as forms or influences upon provisioning wherever there is commodity production even if the first alone of the three involves commodity production as such. Attributes of commodity production, however, can be present without commodity production as such, as with payment for being unemployed or retired, or nominal user charges for public 
This is the version of the article accepted for publication in New Political Economy published by Taylor \& Francis: http://www.tandfonline.com/doi/full/10.1080/13563467.2017.1259304

Accepted version downloaded from SOAS Research Online: http://eprints.soas.ac.uk/23290/

services provided (commodity forms). Commodity calculation prevails when monetary valuation occurs (assessing cost or worth, for example, possibly as basis for action) without money actually passing hands. But, just as commodity production influences the material cultures of other forms of provisioning (what is the meaning of home-made if I can purchase in a shop?) so ccfcc reflect and even facilitate financialisation although they are not financialisation itself.

Nonetheless, because our experiences of financialisation are not direct, within the trading rooms of the City, ccfcc are crucial aspects in the formation of the material culture of financialisation, as these are how we tend to experience financialisation, possibly in paying a water bill, a mortgage or credit card interest. ${ }^{3}$ Thus, our concern is not with the material culture of traders themselves, important though this is, but with the financialisation of everyday life which is experienced at a distance from the 'boiler rooms'. Our general approach to traversing this distance is laid out in Section 4, and how it is to be operationalised in Section 5, by framing specific economic activities through the SoP approach, which seeks to unravel the interactions across monetary forms and the activities with which they are attached or associated. This in turn leads to the framing of corresponding material cultures through use of the 10Cs as previously suggested.

Now, through our analysis, the SoP/10Cs approach can come together with the insights gained from distinguishing between financialisation as such and its consequences through ccfcc. For the material culture of financialisation is associated with pressing for commodity calculation to be more pervasive, for it to lead to commodity form, and for commodity form to lead to commodification. None of this is, however, linear or guaranteed, and it is contradictory in that commodification at one point, housing for example, may condition or even lead to decommodification elsewhere (the hard to house). Nonetheless, commodity calculation is the most pervasive form through which financialisation is materially, and hence 
This is the version of the article accepted for publication in New Political Economy published by Taylor \& Francis: http://www.tandfonline.com/doi/full/10.1080/13563467.2017.1259304

Accepted version downloaded from SOAS Research Online: http://eprints.soas.ac.uk/23290/

culturally, experienced, although not financialisation itself, since it is a pre-condition for both commodity form and commodification, and, in turn, for financialisation, although one or other or all of these can be far removed from the direct experience of everyday life and even more so in how it is interpreted/experienced.

Nor is the presence of commodity calculation unique to the era of financialisation and its material culture, as was recognized by Oscar Wilde’s quip concerning the cynic knowing the price of everything and the value of nothing and, in more scholarly fashion, by Simmel's view not that every relation had become monetised in practice so much as in thought. ${ }^{4}$ This is why, if we are to specify financialisation distinctively, it needs to be in terms of the current period of capitalism, and its attachment to neo-liberalism, a leitmotif throughout our collection, with the corresponding tendency for economic and social reproduction, and its material cultures, to become incorporated into extensive and intensive forms of financialisation.

Although developed to understand the material culture of (commodity) consumption, the SoP/10Cs approach can be usefully extended to the material culture of financialisation. This is taken up in more detail in Fine (this volume) which also serves to frame the other contributions, or case studies, covering financial literacy, exclusion and well-being, housing, water, and the media. The final section here deploys these case studies to illustrate and reflect back upon the approach laid out previously in the introduction - our sequentially structured concretisation of the complexities of material culture through financialisation, ccfcc, the SoP approach and the 10Cs.

\section{Pinning down financialisation}

Sporadic forays apart, over a life of little more than a decade, the notion of 'financialisation' has experienced a meteoric rise, accelerating in prominence in the wake of the global crisis. Significantly, see below, within the discipline of economics, its origins and continuing 
This is the version of the article accepted for publication in New Political Economy published by Taylor \& Francis: http://www.tandfonline.com/doi/full/10.1080/13563467.2017.1259304

Accepted version downloaded from SOAS Research Online: http://eprints.soas.ac.uk/23290/

trajectory remain confined to the heavily marginalised fields of heterodox economics.

Otherwise, as a scholarly 'buzzword' across the social sciences, it borders becoming a 'fuzzword', Cornwall and Eade (eds) (2010). Specifically, it has been deployed with different meanings, methods and theories. As such, it is beginning to carry a similar burden as more longstanding concepts such as globalisation, neoliberalism, and social capital, and has, significantly, overlapped with two of these. ${ }^{5}$ For Epstein (2005: 3), 'In short, this changing landscape has been characterized by the rise of neoliberalism, globalization and financialization'.

Unsurprisingly, debates have emerged around the ambiguity over the meaning of financialisation. These have ranged over the extent, historical uniqueness, likely longevity and homogeneity of the incidence and effects of the rise of finance that financialisation is deemed to capture. ${ }^{6}$

In this introduction, we can hardly resolve continuing debates about whether financialisation is a useful let alone a valid concept. We can, on the basis of the articles in this special issue on the material culture of financialisation address some of the main issues involved. And we do so with the benefits of having undertaken study of financialisation in its complex manifestation as material culture, thereby combining the abstract and general with the concrete and specific.

The first fundamental issue is how to define financialisation. Much of the literature has been casual, reflecting a lack of attention to any theory of finance and inclined to take its (expanded) presence as sufficient for working with pre-existing conceptual frameworks albeit with finance grafted on. Where finance theory is present, it does to some degree conceptually mirror the more casual, generally empiricist approaches, selectively drawing upon theories of finance as appropriate to the specific object of financialised study, whether it be the crisis or the everyday. Collectively, the result is to generate as amorphous a set of theories of 
This is the version of the article accepted for publication in New Political Economy published by Taylor \& Francis: http://www.tandfonline.com/doi/full/10.1080/13563467.2017.1259304

Accepted version downloaded from SOAS Research Online: http://eprints.soas.ac.uk/23290/

financialisation as its scope in practice. ${ }^{7}$ In our own framings, we have sought to avoid such arbitrary intellectual opportunism.

The collective theoretical chaos around financialisation is synthesised, and even celebrated, by Erturk et al. (eds) (2008), identifying the contemporary period as one of 'coupon pool' capitalism. Their approach involves a triangulation of four framings, each deriving from different intellectual traditions and time periods in terms of origins and influence. These are 1930s liberal collectivism, 1980s agency theory, the political economy of quantities (that is more longstanding across heterodox and Marxist schools of economics), and cultural political economy which, in its application to finance, primarily belongs to the new millennium. They are correct both to suggest that these framings are mutually incompatible and that each has something to offer. More questionable, though, is the assertion that these insights cannot be coherently if critically integrated, something that they seem to dismiss on the grounds of the fluid nature of finance itself, and the equally fluid and variable nature of its causes and consequences - financialisation as a veritable 'bricolage' as their favoured term. ${ }^{8}$

The Gordian knot around the theoretical and empirical diversities of financialisation can be cut by adopting a lean and mean definition, not least to address the closely related issue of distinguishing between financialisation and its effects and, thereby, the structures, processes, relations and agencies that yield those effects. Otherwise, by defining financialisation too broadly, it is almost inevitably found to be present and causing with whatever it is associated, just as has been found with globalization and neoliberalism, particularly amongst those inclined towards a culture of critique of grand concepts as opposed to embracing their careless application.

In short, financialisation is in danger of becoming a conceptual fall guy for the legion of inadequacies of contemporary capitalism. In pursuit of a lean and mean alternative to this empirically rich but conceptually incoherent collective posture, our own preference is to refer 
This is the version of the article accepted for publication in New Political Economy published by Taylor \& Francis: http://www.tandfonline.com/doi/full/10.1080/13563467.2017.1259304

Accepted version downloaded from SOAS Research Online: http://eprints.soas.ac.uk/23290/

to Marx’s theory of interest bearing capital, that is, money capital that is advanced in anticipation of a return based on the accumulation of productive capital. Of necessity, interest bearing capital precedes financialisation but the latter can be defined, in a way that is salient for, and specific to, contemporary capitalism. Here we define financialisation, as the intensive and extensive accumulation of interest bearing capital to such an extent that there are qualitative and quantitative transformations in both economic and social reproduction. By intensive is meant what are longstanding if inventively proliferating financial markets, and by extensive is the incorporation of new domains, especially those related to social reproduction such as housing most prominently but also in privatization, commercialization and the varieties of financial intrusions into everyday life (Fine, 2014a). Further, such developments lie at the heart of neoliberalism (Fine and Saad Filho, 2016).

By adopting such a narrow, and abstract, definition of financialisation, the space is opened for tracing the complex and diverse avenues through which it exerts its effects. We have adopted two strategies in this regard. First, financialisation is dependent upon, but not coterminous with monetary relations. Second, financialisation also exerts its influence through non-economic relations, most obviously in the power of finance in political and ideological arenas.

Thus understood, financialisation does not include the advance of all capital, let alone monetary relations, whether for industrial or commercial purposes, because capital might be funded from retained earnings or whatever rather than borrowing from which a return is anticipated. Only the latter case involves financialisation in that a claim on earnings is created and can be bought and sold separately in what Marx termed fictitious capital. Of course, the current period has witnessed the massive expansion of such interest bearing (and fictitious) capital in intensive form, as has been recognized in the stakeholder value literature on 
This is the version of the article accepted for publication in New Political Economy published by Taylor \& Francis: http://www.tandfonline.com/doi/full/10.1080/13563467.2017.1259304

Accepted version downloaded from SOAS Research Online: http://eprints.soas.ac.uk/23290/

financialisation, although it extends much further than this in the proliferation of types and growth of financial derivatives.

Three fundamental features mark the rise of financialisation across the social sciences, pointing to and to some degree explaining its lack of conceptual tightness. One is the frequent observation of the neglect of finance in the past. Typical, for example, is Pike and Pollard (2010: 29), for whom there are, 'long-standing concerns about the relatively marginal location of finance in economic geography’. Similarly, Moran and Payne (2014: 335) observe the limited attention to (the power of) finance in political science due to its concern with the state:

In sum, with economics asserting a monopoly in the study of economic life and international political economy largely content with overarching analyses of global trends, political science was able, on the whole successfully, to assert and claim its own monopoly, so to speak, of the study of the state, and to do it, as we have seen, in its own distinctive way.

Second, possibly in reaction to such neglect, and as has already been acknowledged, is the wide variety of approaches taken to financialisation, ranging from the neo-liberal subject as worker, consumer, entrepreneur, or investor as in Langley (2007) to the 'state of the art' of for van der Zwan (2014), with its straddling approaches to the nature of contemporary capitalism, shareholder value and everyday life. Third, closely related but distinct, is the equally wide variety of subject matter covered by financialisation, dealing in everything from the nature of the relationship between financialisation and neoliberalism in characterising contemporary capitalism to the pervasive influence of financialisation on everyday life, let alone as a generic term for finance itself (Sawyer 2014).

No doubt, much of the way in which financialisation is approached is a consequence of the weight and diversity of finance in general, however it is understood, with an equally 
This is the version of the article accepted for publication in New Political Economy published by Taylor \& Francis: http://www.tandfonline.com/doi/full/10.1080/13563467.2017.1259304

Accepted version downloaded from SOAS Research Online: http://eprints.soas.ac.uk/23290/

compelling fluidity and innovation attached to its conceptualisation (as with other 'grand' concepts). Significantly, then, as proposed by Lee et al. (2009: 727-8), in locating it geographically even at an early stage, 'financialisation is hardly a new phenomenon in circuits of capital. What is perhaps relatively new is the extent to which finance has found its way into most, if not all, of the nooks and crannies of social life. To illustrate, it is easily possible to identify at least 17 notions of financialisation'. The bridge(s) from our tight definition of financialisation to this array of approaches and subject matter to which the term has been attached is provided below by the trilogy of commodification, commodity form, and commodity calculation, ccfcc, which both underpin financialisation and mediate social and economic reproduction.

\section{Commodification, commodity form and commodity calculation - ccfcc}

Financialisation, understood as the increased deployment of interest bearing capital, is intimately connected to, though distinct from, the monetary relations attached to commodity production. First, capitalist commodity production, and its extension through commodification (privatisation of public services for example), provides fertile ground for financialisation. In addition, financialisation can prosper where there is not necessarily commodity production but the presence of the 'commodity form' by which is meant monetary payments (most notably for mortgages for example) which generate revenue streams that can be securitised as assets and be speculatively traded as interest bearing capitals. The roll out of both commodity production proper, that is for profit, and of the commodity form, that is, payment for goods that are not necessarily produced for profit, have greatly facilitated financialisation by creating more opportunities for the securitisation of revenue streams and capture of monetary rewards by finance. By contrast, commodity calculation - the use of monetary criteria in decision making despite the relevant relations not actually being monetised - does not provide the same opportunities for financialisation due to 
This is the version of the article accepted for publication in New Political Economy published by Taylor \& Francis: http://www.tandfonline.com/doi/full/10.1080/13563467.2017.1259304

Accepted version downloaded from SOAS Research Online: http://eprints.soas.ac.uk/23290/

the absence of revenue streams, but is nonetheless a ubiquitous feature of material culture in financialised economies.

Necessarily, with our definition, financialisation depends upon commodity production, by which we mean production for profit, since monetary rewards ultimately derive from such production (as finance never made any return by itself other than appropriating it from elsewhere as a result of the putative trading in risk or providing financial services). ${ }^{9}$ Accordingly, the most prominent form in which everyday life says hello to financialisation is in the indirect form of any monetary exchange, buying and selling, creating the presumption in much of the literature that commodity production (or its creation through commodification) is part and parcel of financialisation. Yet commodity production as such may not involve finance at all as in the case of cash purchases (although financialisation may well have occurred intensively further up the chain of provision to make that cash available). But, equally, commodity production for consumption has increasingly become embroiled in credit relations, most notably with mortgages, credit cards, and so on. ${ }^{10}$

Such is not financialisation as such by our tight definition as interest bearing capital. Mortgages have long existed, for example. What makes them financialisation is the securitisation of the potential interest payments (or the debts as such) and their bundling into derivatives for speculative purposes. Yet, as observed, one implication is that (re)commodification, even if not financialisation itself, offers fertile opportunities for financialisation, both in the productive sphere (as with privatization and corresponding creation of financial assets representing ownership) and with its 'weaker' counterparts of commercialisation with user charges, public private partnerships, and contracting out. The associated revenues of such operations offer the scope for securitization and, so financialisation, that may or may not (be allowed to) take place. ${ }^{11}$ 
This is the version of the article accepted for publication in New Political Economy published by Taylor \& Francis: http://www.tandfonline.com/doi/full/10.1080/13563467.2017.1259304

Accepted version downloaded from SOAS Research Online: http://eprints.soas.ac.uk/23290/

A leading example of the commodity form is pensions, not covered in this collection but subject to future work, ${ }^{12}$ for which this increasingly prominent element of social reproduction (of the aged) has been subject to individual responsibilisation, driven by, and as a consequence of, financialisation. This has given rise to a set of rich and contradictory cultures as a result of the clash of financialisation of pensions with a traditional ethos of collective provision for the retired, not least in the wake of the variously understood crises of pension systems (putatively assigned to a demographic time bomb). Apart from the narrowly interpreted parameters of pension systems themselves (levels of payments by whom, with what rewards), how these have been constructed on a broader perspective depends upon differential access to, participation within, and rewards from labour markets, the taxation systems and the levels of provision of social or familial welfare provision outside of the pension system, quite apart from the vagaries of financial returns when these are a proximate determinant of individual or collective pensions. ${ }^{13}$

The relationship between pensions and finance offers a salient example of why it is necessary to distinguish between commodification and commodity form in engaging with (the cultural) effects of financialisation. For pensions have been financialised but not, in general, in the direct experience and knowledge of pensioners themselves! Yet, commodification and commodity forms both only create the basis for financialisation, and hence condition its material culture indirectly. The same potentiality does not prevail, at least to the same degree, of what might be termed commodity calculation, in which some sorts of monetary calculations are made but in the absence of monetary exchange itself (in traditional terms, cost-benefit analysis). Brown (2015: 10) identifies commodity calculation in extreme form, exaggerating the extent to which Foucauldian reason is and can be realised in neoliberal practice, 'All conduct is economic conduct: all spheres of existence are framed and measured 
This is the version of the article accepted for publication in New Political Economy published by Taylor \& Francis: http://www.tandfonline.com/doi/full/10.1080/13563467.2017.1259304

Accepted version downloaded from SOAS Research Online: http://eprints.soas.ac.uk/23290/

by economic terms and metric, even when those spheres are not directly monetized... we are only and everywhere homo oeconomicus'.

As with commodities and commodity form, the presence of commodity calculation is not itself financialisation, although often conceived as if so when notions, such as the neoliberalisation of this or that, are interpreted as its financialisation, not least in the university for example, and in the adoption of commercial criteria but not commerce itself in provision of public services. ${ }^{14}$ But, unlike the other two, commodity calculation is not capable as such of providing the basis for financialisation, as we have defined it at least, as there is no monetary exchange, nor flows of income, as such, to be securitised.

The benefits of approaching financialisation through a tight, i.e. narrow and precise, but abstract definition is that it allows for diversity of outcome through the troika of ccfcc, distinguishing financialisation from its effects rather than reducing or, more exactly, expanding the notion of financialisation to include the general, if multiple and diverse, presences and influences of all monetary exchange, calculation and ethos. Thus, similar to us, Jessop (2015) appropriately sees cash, credit and fictitious capital as fetishised forms of social relations. ${ }^{15}$ But it remains necessary to specify those relations, the fetishes and the corresponding connections between them - as is our purpose in this collection.

In addition, apart from approaching the broader impact of financialisation through ccfcc, the intensive and extensive expansion of interest bearing capital points to the increasingly direct and indirect roles of financialisation in economic and social reproduction and restructuring. ${ }^{16}$ This is, of course, a prominent theme in the political economy literature on financialisation, especially for the economic, with financialisation, from a variety of perspectives generally and understandably seen as having deleterious effects on performance whether it be through short-termism, growth, employment, distribution or stability. ${ }^{17}$ 
This is the version of the article accepted for publication in New Political Economy published by Taylor \& Francis: http://www.tandfonline.com/doi/full/10.1080/13563467.2017.1259304

Accepted version downloaded from SOAS Research Online: http://eprints.soas.ac.uk/23290/

This, however, points to a major issue to be confronted however financialisation is defined. If understanding of it is to move beyond the acknowledgement of the greater presence and power of finance, it requires systemic understanding of the contemporary period. What are the dynamics of capitalism in the presence of financialisation and how do they differ from those that came before? In this respect, we have argued at great length that financialisation can be understood as underpinning neo-liberalism which we take to be the current stage of capitalism, (Bayliss et al. 2015 and Fine and Saad Filho 2016)), and correspondingly influential over the neoliberalisation of everyday life. This is not to reduce neo-liberalism to financialisation but to perceive the last thirty years as having witnessed considerable intervention on the part of the state to promote (the processes, interests, and so on, associated with) financialisation. To some extent, it is precisely this systemic and dynamic significance of financialisation for contemporary capitalism that renders it, like globalisation and neoliberalism, so suitable for adoption by the social sciences in which it can sit comfortably across a variety of methods and disciplines despite, or even because of, a collective lack of coherences. The major, perverse, exception is mainstream economics, in contrast to heterodox political economy, for it is incapable of addressing the systemic and the historically dynamic.

Further, though, in locating financialisation in a systemic context, there is an equal need to address its diversity, not only in its content, forms and incidence but also in its impacts. Reference to ccfcc, and attachment of these to neoliberal economic and social reproduction, is to open rather than to close analyses. In this respect, for example, the renewal of interest in Polanyian double movement is welcome. ${ }^{18}$ However, it is also limited because the movements are not confined to finance, land and labour, and nor are we witnessing a double movement between commodity and non-commodity forms. Instead, financialisation impacts on a multi-dimensional and differentiated set of movements across all economic and social 
This is the version of the article accepted for publication in New Political Economy published by Taylor \& Francis: http://www.tandfonline.com/doi/full/10.1080/13563467.2017.1259304

Accepted version downloaded from SOAS Research Online: http://eprints.soas.ac.uk/23290/

reproduction, with corresponding resistances and contingent outcomes in circumstances of everyday lives that those that live them do not make themselves and of which they may be only distantly conscious.

\section{From financialisation to culture}

In the previous section, we have sought to define financialisation in a particular way and to prepare the ground for examining its incidence and its effects by carefully distinguishing financialisation as such from the troika of ccfcc which can be pre-requisites but are not financialisation itself. This provides the foundation for the focus of this special issue on the transformative impact of financialisation on households and everyday life. The expanded presence of finance in social reproduction, and the ways in which households have become increasingly embroiled in financial markets, has been extensively documented elsewhere (Martin 2002; Langley, 2008; Montgomerie, 2009; Seabrooke, 2010; Brassett et al. 2010; Froud et al. 2002; Pike and Pollard 2010, Haiven 2014). Building on this work, our interest is in how the dominance of finance has taken root and manifested at a subjective level, and how it has in turn transformed agents' subjectivities: ${ }^{19}$

With the growth of what is termed 'financialisation', the widening breadth and scope of financial markets has (sic) been inherently bound up in transformations in terms of how individuals live their lives: their habits and reflexive choices, their modalities of self-discipline and their subjectivities (Marron, 2013: 787).

The multiple forms taken by households' engagement with financial markets are, therefore, explored alongside the often contradictory formation of the subjectivities that underpin these material practices (Froud et al. 2007). This means attending to how the needs, ideas and meanings attached to finance have facilitated finance's encroachment into everyday life, and the transformative implications for people's lives and self-understandings. In short, the contributions in this special issue collectively endeavour to study the material cultures of 
This is the version of the article accepted for publication in New Political Economy published by Taylor \& Francis: http://www.tandfonline.com/doi/full/10.1080/13563467.2017.1259304

Accepted version downloaded from SOAS Research Online: http://eprints.soas.ac.uk/23290/

financialisation. The goal is to begin to grasp, on the one hand, 'the way in which financial risk, metrics and practices have become bound up with and normalised through everyday activities such as buying or improving a home; learning and obtaining skills; having children and providing for old age (Christopherson et al. 2013: 354) and, on the other, the structures and configurations of economic, political, and cultural power that underpin this normalisation.

As Christopherson et al. rightly note,

An acceptance of the relationship of financial processes to changing subjectivities and understanding of the self and society contravenes conventional beliefs about the economy as a separate sphere and personhood as fixed over time in relation to changing economic roles, practices and expectations (see Pollard, 2013). Instead, it emphasises a broader anthropological conception of economic activity as encompassing a 'way of life' that is mutable and socially structured. (Christopherson et al. 2013: 354).

Accordingly, our work is situated within the 'cultural turn' in political economy, which rejects old binaries in favour of the hybridisation of culture and economy and of use value and exchange value (Barnes, 2004). This reorientation is motivated by the recognition that culture is rooted in the material world: '[c]ulture exists neither in our minds, nor does it exist independently in the world around us, but rather is an emergent property of the relationship between persons and things' (Graves-Brown, 2000: 4). Further, it is imperative to acknowledge in turn that economies are 'formatted by discourses' (Montgomerie, 2009: 2) and hence that we need 'cultural terms such as symbol, imaginary, and rationality ... to understand crucial economic processes’ (Peet, 2000: 1213). Addressing culture’s material foundation opens the door to comprehending the role of economic and political power in shaping financialised cultural forms, including, without being limited to, 'the extent to which 
This is the version of the article accepted for publication in New Political Economy published by Taylor \& Francis: http://www.tandfonline.com/doi/full/10.1080/13563467.2017.1259304

Accepted version downloaded from SOAS Research Online: http://eprints.soas.ac.uk/23290/

elite actors can sway public opinion and assist in the framing of incentive structures’ (Seabrooke, 2010: 57). However, such considerations exist in conjunction with agents' capacities for reflection and resistance. These in turn focus attention on how dominant norms attain legitimacy and compliance in terms of Foucauldian ideas of governmentality: ‘in principle a legitimate social system can only function through 'cumulative, individual acts of compliance or confidence’ by non-elites towards those who seek to govern’ (Bendix quoted in Seabrooke, 2010: 57; see also Stanley, 2014).

\section{The system of provision approach - and the 10Cs}

The challenge for such a cultural political economy is how to pay due recognition to cultural specificity, the efficacy of cultural properties, agent reflexivity, and the co-constitution of subject and object, while 'continu[ing] to emphasize the materiality of social relations and the constraints involved in processes that also operate 'behind the backs' of the relevant agents' (Jessop and Sum, 2001: 94). To meet this challenge, we draw on the systems of provision, SoP, approach, which sees the economy as constituted by overlapping, commodity-specific systems of provision. These SoPs are defined in terms of the structures, agents, processes and relations that characterise the entire chain of provision underpinning particular commodities. The operation of a SoP is shaped by multiple factors - social, political, economic, geographic and historical - and in turn gives rise to distinct, commodity-specific cultures of consumption, the pattern of practices, ideas and meanings that shape patterns of consumption. For the SoP approach, then: ${ }^{20}$

The material properties of a good or service fundamentally affect consumption patterns (for example water has different material attributes from housing) and goods and services are imbued (often subtly) with cultural significance. ... For the narrowlydefined physical characteristics attached to provision, and consumption, are necessarily culturally endowed in the widest sense. Such cultural content is also 
This is the version of the article accepted for publication in New Political Economy published by Taylor \& Francis: http://www.tandfonline.com/doi/full/10.1080/13563467.2017.1259304

Accepted version downloaded from SOAS Research Online: http://eprints.soas.ac.uk/23290/

subject to wider considerations that range far beyond the immediate provision of the good itself (such as gender, class and nationality). Each sop needs to be addressed by reference to the material and cultural specificities that take account of the whole chain of activity, bringing together production, distribution, access, and the nature and influence of the conditions under which these occur (Bayliss et al. 2013: 1).

Significantly, the SoP approach is consistent with different methods and conceptualisations and does not have to be applied alongside our own understanding of financialisation as laid out above. This is, though, the way in which we address the material cultures of financialisation offered here.

In particular, elsewhere (Bayliss et al. 2013; Bayliss 2014; Robertson 2014), we have used the SoP approach to investigate the role and impact of finance and financialisation on housing and water. ${ }^{21}$ By locating finance within the integrated chains of provision of these two commodities, we were able to reveal how both have been restructured along the chain of provision by the expanded and transformed presence of finance. Given that our present interest is more upon the household, we focus more specifically on the point of consumption, and the desires, meanings and understandings - the cultures of consumption - to which the SoP as a whole gives rise. To do so, we adopt a further framing through which such cultures are addressed deploying what is known as the 10Cs that have become part and parcel of the SoP approach to the material culture of consumption. The purpose of the 10Cs is to provide guidance for the full comprehension of consumption cultures and how they are constituted, through the identification of ten characteristics common to all such cultures. These are: Constructed, Construed, Conforming, Commodified, Contextual, Contradictory, Closed, Contested, Collective, and Chaotic. Once again, as with the SoP approach itself, use of the 10Cs is compatible with different approaches, and is applicable to a range of subject matter 
This is the version of the article accepted for publication in New Political Economy published by Taylor \& Francis: http://www.tandfonline.com/doi/full/10.1080/13563467.2017.1259304

Accepted version downloaded from SOAS Research Online: http://eprints.soas.ac.uk/23290/

(and not just consumption), albeit with strong resonances to its origins within Marxist political economy. ${ }^{22}$

The complex characterization of consumption cultures, across at least these ten dimensions, mitigates against any tendency to exaggerate the extent of financialisation’s cultural hegemony by drawing attention to agents’ capacities for reflection and resistance, as well as the multi-faceted influences on their subjectivities that derive from factors more distant than acts of financing, purchasing and consuming. The 10Cs also facilitate a deconstruction of these influences, in discursive terms and in terms of economic and political power. In short, they present a holistic understanding of the multiple channels through which the Foucauldian governance of the financialisation of everyday life is maintained, in conjunction with any dissonances in how financialisation is practised and perceived, the latter emphasised by Haiven (2014) as itself constitutive of financialisation.

As is apparent, then, not least across the case studies included in this symposium, the impact of financialisation is to strengthen and broaden the ethos of commodity calculation, through financial literacy, the media, the promotion of the homeowner and, perversely, through dichotomising it with an alter ego of financial exclusion or well-being independent of financial affairs. It is highly conducive to perceiving the economy, and ideologically promoted as such, as if a household, weighing economic and non-economic imperatives against one another but with Micawberite financial balance as the priority of both national and everyday life as opposed to provision independent of market logics (Stanley 2014). Commodity calculation does its work by occupying the space of material culture and excluding other tenants, especially those associated with the ethos of collective and nonmarket forms of provision, lest it be for those who are not in and cannot be in the market. In short, as with capitalist commodity production more generally, territories are laid out by financialisation on which it does or does not prevail in economic and social reproduction. 
This is the version of the article accepted for publication in New Political Economy published by Taylor \& Francis: http://www.tandfonline.com/doi/full/10.1080/13563467.2017.1259304

Accepted version downloaded from SOAS Research Online: http://eprints.soas.ac.uk/23290/

What goes on outside of its narrowly confined borders of interest bearing capital is complex and varied but far from independent of what goes on inside, motivating OUR complex of analytical framings on offer.

\section{The material culture of financialisation in practice}

As illustrated by our case studies, this is where the SoP/10Cs/ccfcc approach is intended to do its work. The SoP approach provides a framework through which to explore interactions between ccfcc and financialisation within particular SoPs, while the 10Cs serve as the means to characterise the emergent material culture associated with that SoP. Our case studies deploy this approach in two different ways. There are those that look at the 'financial SoP' itself, along with how broader facets of its material culture manifest across society, including through the media, financial literacy, financial inclusion, and happiness economics. Then there are those that look at how the SoPs for particular commodities - namely, housing and water - have been restructured by financialisation, and with what implications for their consumption cultures in terms of the 10Cs.

A serious and obvious challenge, not explicitly addressed here, in applying the SoP approach to the material culture of financialisation is how SoPs are to be defined and distinguished from one another. As Fine notes in the opening paper in the symposium, financial services themselves are not a commodity in any straightforward sense. While they include an array of (speculative) assets and (credit-related) services that are not readily categorized in terms of either consumption or production other than by inappropriately stretching the meanings of these terms, they are, nonetheless, subject to material practices in how they are constructed and accessed, and in how they have effects. There is, after all, a financial system that can itself be interpreted as a SoP. This is the procedure adopted by Fine in dealing with the nature of the financial system as a whole, and how it impinges on everyday lives. He goes on to examine the material culture of the financial system through the lens of the 10Cs. As well as 
This is the version of the article accepted for publication in New Political Economy published by Taylor \& Francis: http://www.tandfonline.com/doi/full/10.1080/13563467.2017.1259304

Accepted version downloaded from SOAS Research Online: http://eprints.soas.ac.uk/23290/

dissecting the material culture of the financial SoP, his paper serves to elaborate further on the 10Cs, both broadening the theoretical outlook outlined in this introduction and furnishing perspective for the other papers that follow. This paves the way for the examination of the influence of financialised material culture across society, through case studies on the media, financial literacy, and financial exclusion.

Significantly, other than for housing and water, none of our case studies, focusing upon the material culture of the financialisation of everyday life, bears upon financialisation directly, as the expansion of interest bearing capital. This is because, as observed through the prism of ccfcc, such activities take place behind the backs not only of 'consumers' but also even of many of the producers and commercial operatives as well, even though it is well-observed in the financialisation literature how extensive and important are the profits that derive from the financial arms of non-financial companies.

By virtue, then, of both the 'distance' of such financial operations from the nitty-gritty of everyday life and their intrinsic complexity, ${ }^{23}$ the material culture of financialisation is far removed from direct 'knowledge' or experience of such activity and so, accordingly, is only engaged as such indirectly. But, as Fine closely argues, in light of the 10Cs and in parallel with the dysfunctional distribution and consumption of food, such (lack of) knowledge is not primarily, and certainly not purely, a consequence of such distance. Indeed, our everyday knowledge of food, and its effects given obesity at epidemic proportions, is extensive and often, if ignored, knowable and known within everyday life, however much observed in the breach. The major difference with finance, intensified by financialisation, is that we not only are ignorant of its dynamic chaos but that, as such, it is systemically unknowable in its own way, with corresponding results filtering down to everyday lives, occasionally acutely in case of crisis just as chronically in the case of the diets of affluence. 
This is the version of the article accepted for publication in New Political Economy published by Taylor \& Francis: http://www.tandfonline.com/doi/full/10.1080/13563467.2017.1259304

Accepted version downloaded from SOAS Research Online: http://eprints.soas.ac.uk/23290/

The point, then, is not that the food, in contrast to the financial system is knowable - after all it has been subject to (unknowable) crises of its own from mad cow to horsegate - but that the nature of knowledge, and corresponding cultures, are specific to how food and finance are differentially organised (which the SoP/10Cs approach seeks to address in each case). In general, and hardly unsurprisingly, the way in which the unfillable gap in the financial knowledge of everyday life is accommodated is one that essentially turns a blind eye to its fundamental feature of systemic uncertainty, either through individual reliance upon the practices and experiences of managing individual financial affairs or through addressing these more collectively as a form of Foucauldian governance.

This syndrome is beautifully illustrated by other papers in the collection. Santos, through a study of financial literacy programmes and their promotion through national and international bodies, argues that, despite their many contradictions, such programmes perform an ideological function of inculcating calculating and individualist attitudes among individuals. Financial literacy programmes are specifically designed to insert the financial subject into a world in which the external environment is admittedly uncertain but in which the subject can get by if only gaining and applying the appropriate knowledge.

Gabor and Brooks trace the rise of financial inclusion as a model of development cooperation, focusing in particular on the growing role of digital technology in capturing data on individual consumer behaviour. What they term the fintech-philanthropy-development complex has served both to incorporate the poor into financial markets by allowing for cheaper and easier assessment of consumer behaviour and credit scores, and to shape and therefore govern financialised subjectivities. The explicit tying of financial inclusion discourses to the Foucaldian production and maintenance of the financialised subject facilitates the attribution of market failure to individual behavioural traits rather than to poor regulation of systemic dysfunctionality of financial markets and institutions, something 
This is the version of the article accepted for publication in New Political Economy published by Taylor \& Francis: http://www.tandfonline.com/doi/full/10.1080/13563467.2017.1259304

Accepted version downloaded from SOAS Research Online: http://eprints.soas.ac.uk/23290/

which in turn channels policy responses to addressing individual capability rather than systemic instability.

Boffo, Brown and Spencer offer a critique of the turn towards happiness economics as a metric of well-being for its failure to take into account cultural interferences in reported happiness, with emphasis placed on the Contextual to be understood through political economy (of the Global Financial Crisis). Well-being, they argue, and the myriad ways in which it has been affected by financialisation, can only be comprehended through the integrated study of how perceptions of needs and wants are constituted, and how their satisfaction is facilitated or constrained. Measures of well-being proceed oblivious to the views that its subjects might have over the workings of the financial system, how it reduces their aspirations, and can allow for limited shifts in reports of happiness despite devastating reductions in standards of living.

Across each of these papers, if for a different topic with correspondingly different aspects, there are common elements. One is how the individual is taken as starting point - for lessons in financial literacy, for support out of financial hardship, or for assessment of well-being, respectively. Another is how these starting points are not tied at all, or at most in the most superficial and erroneous fashion, to the systemic functioning of finance. All can be financially literate, all can be financially included, and happiness begins and ends at home irrespective of how it has been delivered there as long as it has been. In contrast, the SoP/10Cs approach directs attention to the material culture of financialisation in denying knowledge of the financial system (from the extent of government support to its iniquitous rewards through to its inability to be governed), in promoting financial exclusion as a condition of financial inclusion, and in reducing aspirations in reporting well-being. The material cultures of financialisation do not, of course, pertain only to the financial system itself. The financialisation of everyday life has led finance to intersect more extensively with 
This is the version of the article accepted for publication in New Political Economy published by Taylor \& Francis: http://www.tandfonline.com/doi/full/10.1080/13563467.2017.1259304

Accepted version downloaded from SOAS Research Online: http://eprints.soas.ac.uk/23290/

the other SoPs implicated in social reproduction, reshaping the material practices and consumption cultures associated with those SoPs. The material cultures of financialisation must therefore be approached from the perspective of both the material culture of the financial system itself, and that of the material cultures created through the financialisation of other SoPs and other activities. Happer’s paper helps to bridge these two perspectives by looking at the role of the media in shaping perceptions and understandings of the financial system, and explaining this role in terms of the structures underpinning the production and dispersion of information. Complementing the SoP approach with a circuit of communication model, she finds that reduced democratic accountability, a revolving door between the political, financial, and media sectors, and journalistic reliance on expert financial knowledge have all played their part in marginalising media narratives that are critical of financialisation and its effects. Moreover, precisely in the representation of finance and of the crisis in the media, in the absence of direct experience of its workings, the knowledge gap is filled by those experts and commentators who are generally heavily implicated in securing its interests, representing its views and precluding alternative forms of financial let alone economic and social organization.

Similarly, Robertson's paper, in part, offers an illustration of the role of the media in promoting, and condoning, financialisation through close attention to the way it has, in conjunction with government discourses and material advantages, promoted owneroccupation as the most favoured form of housing tenure. Robertson draws attention away from the financial system per se to look at the financialisation of the housing sector. Taking mortgage-facilitated owner-occupation as the defining feature of financialised housing provision, Robertson investigates how a desire for owner-occupation has been inculcated and normalized in the UK. The discursive reshaping of the meanings and perceptions attached to owner-occupation emerges as a key part of the story. The paper also exposes the roots of 
This is the version of the article accepted for publication in New Political Economy published by Taylor \& Francis: http://www.tandfonline.com/doi/full/10.1080/13563467.2017.1259304

Accepted version downloaded from SOAS Research Online: http://eprints.soas.ac.uk/23290/

these normalizing discourses in the economic and political power imbalances that are part and product of a financialised economy such as Britain’s.

Thus, the financialisation of the housing SoP is located at a distance from those taking out mortgages. On the face of it, subject to terms and conditions, buying a house through a mortgage in the UK today is no different than in the previous 100 years or more even though what was primarily a system of not-for-profit building society provision has been displaced by for-profit banking provision. But, as Robertson shows, such a shift in the forms of financial provision, even if away from the borrower as such, has contributed to a profound shift in the UK in the material culture of housing towards one unambiguously favouring individual private homeownership (as well as this being underpinned by genuine advantages to those who achieve it in the marginalised forms or quality of alternative tenures). Moreover, although common to a greater or lesser extent across many countries, this shift is not reducible simply to the greater availability of mortgage finance but this in conjunction with the conditions of housing supply, including access to land, the role of the state and planning system, and the nature of the construction industry - reinforcing the virtues of approaching the material culture of (housing) finance through the prism of the SoP/10Cs approach. Whereas the financialisation of housing has been associated with changes in the consumption practices and perceptions of consumers, Bayliss’s contribution shows how the financialisation of water has taken place behind consumers' backs. Water privatization in England and Wales precipitated the emergence of highly leveraged corporate structures used to extract and transfer surpluses to shareholders. Household water bills are rising as a result, though consumers remain overwhelmingly unaware of why. Part of the reason for this is that the financial structures underpinning water companies remain opaque, while households have experienced no change in how they consume water - namely, from the tap, whilst their payments are tapped in entirely different ways. What has occurred is a shift away from an 
This is the version of the article accepted for publication in New Political Economy published by Taylor \& Francis: http://www.tandfonline.com/doi/full/10.1080/13563467.2017.1259304

Accepted version downloaded from SOAS Research Online: http://eprints.soas.ac.uk/23290/

ethos of public provision of water towards treatment of water as a commodity, with an associated emphasis on individual responsibility for paying water bills and for the hardship that may arise from an inability to do so. Yet, the hidden nature of households' incorporation into global financial circuits has dampened contestation and resistance to water privatization in England and Wales compared to other parts of the world, something compounded by the regulator's permissive attitude towards water companies’ financial dealings.

The upshot of this attention to how other SoPs are affected by financialisation is three-fold. First, that there are multiple, competing, and contradictory pressures on material practices and cultures across commodities. Second, that, reflecting distributional and other inequalities, different agents and groups are differentially affected by financialisation. And, finally, that both of these features give rise to limitations and, potentially, resistance to the financialisation of everyday life. All of this serves as a reminder that, 'financialisation does not impose one new logic, but makes and remakes the world in complex ways' (Froud et al. 2007: 343). ${ }^{24}$ This is precisely why the SoP and 10Cs approach offers some insight into material cultures attached to financialisation, why resistances have been so muted, and how this might become otherwise.

\section{$\underline{\text { Footnotes }}$}

${ }^{1}$ Thanks to Brett Christophers and Johnna Montgomerie for extensive comments on this introduction and the symposium contributions, leading to great improvement in both content and clarity.

${ }^{2}$ Space does not allow account of these, our own approach, nor how to accommodate new forms of money from private credit creation to electronic money.

${ }^{3}$ Although some see households themselves as essentially financialised (Martin 20012; Bryan and Rafferty 2014). 
This is the version of the article accepted for publication in New Political Economy published by Taylor \& Francis: http://www.tandfonline.com/doi/full/10.1080/13563467.2017.1259304

Accepted version downloaded from SOAS Research Online: http://eprints.soas.ac.uk/23290/

${ }^{4}$ See Simmel's The Philosophy of Money, published in 1900, and commentary by Dodd (1994), and also (Gronow 1997; Fine 2002).

${ }^{5}$ Social capital has studiously avoided its most obvious application, to (international) elites, especially those attached to finance (Fine 2010) and, implicitly, (Vitali et al 2011).

${ }^{6}$ See Michell and Toporowski (2015) but especially Christophers (2015a and b) and responses in the corresponding special issue.

${ }^{7}$ This can be seen positively, as with Aalbers (2015, p. 215/6):

The literature on financialization thus is part of a larger attempt to understand the nonlinear, multidimensional, multi-scalar complexity of contemporary societies/economies ... [with] potential for financialization as a concept facilitating the conversations between different (sub)disciplines that otherwise do not necessarily talk much to each other ... The power of the financialization literature is not only that it connects different disciplines but also different levels of analysis, from the very micro to the very macro - and demonstrating how these are related.

${ }^{8}$ See also Johal et al (2014) for use of bricolage in the context of the power of finance.

${ }^{9}$ For an outstanding account of how finance as productive has been rationalised, see Christophers (2013).

${ }^{10}$ With a corresponding notion that everyone is financially exploited, Lapavitsas (2013) and Fine (2010 and 2014) for critique, or that the household is necessarily forced into being the equivalent of a financial operative (Bryan and Rafferty 2014).

${ }^{11}$ See Leyshon and Thrift (2007) for the early, if implicit, suggestion that financialisation be reduced to capitalization/securitization.

${ }^{12}$ But see Saritas (2013) and Churchill (2014) 
This is the version of the article accepted for publication in New Political Economy published by Taylor \& Francis: http://www.tandfonline.com/doi/full/10.1080/13563467.2017.1259304

Accepted version downloaded from SOAS Research Online: http://eprints.soas.ac.uk/23290/

${ }^{13}$ Significantly, the SoP/10Cs approach adopted here, see below, is capable of addressing how such wide-ranging systemic factors feed into the shifting cultures of what pensions are and what they mean.

${ }^{14}$ See Engelen et al (2014), Martin (2011) and Morrish and Sauntson (2013), and also Graeber (2014) and http://www.ft.com/cms/s/2/c662168a-38c5-11e6-a780b48ed7b6126f.html

${ }^{15}$ Less precisely, Haiven (2014, p. 5) refers to 'Rhizomatic manifestations throughout social and cultural life' and 'deep penetration of financial ideas, tropes, logics and processes into the fabric of everyday life', p. 18.

${ }^{16}$ Other than as a general source of financial exploitation in response to the attempt to sustain standards of living in response to austerity, (Lapavitsas 2013) most prominently, attention to the impact of financialisation on social (as opposed to household) reproduction, especially social policy, has been much more limited if not negligent. See emphasis by Elson (2014) in passing and Fine (2014b).

${ }^{17}$ Varieties of post-Keynesianism and Marxism have been to the fore, see special issue of International Journal of Political Economy, 42 (4), 2014, and for regulationist approaches, conveniently suffering amnesia over the putatively intermediate post-fordist regime and converging with what might be termed institutional post-Keynesianism, see Aglietta and Rebérioux (2012) and Boyer (2013) for micro and macro aspects, respectively.

${ }^{18}$ For a favourable review of Polanyi in light of financialisation that implicitly confirms our more critical stance, see Scheiring (2016).

${ }^{19}$ And for Haiven (2014: 14), ‘financialization also means a moment when the financial system, and the capitalist economy of which it is a part, is dependent on and invested in the ideologies, practices and fictions of daily life as never before’. 
This is the version of the article accepted for publication in New Political Economy published by Taylor \& Francis: http://www.tandfonline.com/doi/full/10.1080/13563467.2017.1259304

Accepted version downloaded from SOAS Research Online: http://eprints.soas.ac.uk/23290/

${ }^{20}$ The SoP approach first appeared in print in Fine and Leopold (1990) in debating the putative UK Consumer Revolution of the eighteenth century. It was fully laid out in Fine and Leopold (1993) but see other references cited here, and Fine (2013) for a retrospective account that distinguishes its origins and methods from the global value/commodity chain approach.

${ }^{21}$ These papers were prepared as part of the EU-funded research programme Financialisation, economy, society and sustainable development (FESSUD) fessud.eu. ${ }^{22}$ The 10Cs approach has been adopted as a general approach to material culture as is apparent from its application to public provision and social policy (Fine 2002 and 2014), and to topics such as identity (Fine 2009a and b), the ethics of economics (Fine 2013), and (international) legal expertise (Fine 2016).

${ }^{23}$ Even testing the limits of academics, whose knowledge of the 'markets' often remains a black box, see Poovey (2015) and Christophers (2015b).

${ }^{24}$ And, in addition, it is crucial to avoid the two, increasingly clichéd, logics associated with financialisation: on the one hand, especially in the context of everyday life, the unemployed or low waged household, public service deprived and over-indebted on mortgage and credit cards desperately seeking to sustain norms of consumption, see Karacimen (2014) and Santos et al (2013) and Santos and Teles (2014); and, on the other, the fat cat financier responsible for low investment and growth, rising inequality and speculative crises. No doubt, these exist but they are in part misleading in understanding the nature, incidence, driving forces and consequences of financialisation, see Bayliss et al (Deliverable). 
This is the version of the article accepted for publication in New Political Economy published by Taylor \& Francis:

http://www.tandfonline.com/doi/full/10.1080/13563467.2017.1259304

Accepted version downloaded from SOAS Research Online: http://eprints.soas.ac.uk/23290/

\section{References}

Aalbers, M. (2015), ‘The Potential for Financialization’, Dialogues in Human Geography, 5 (2), pp. 214-19.

Aglietta, M. and Rebérioux, A. (2012), 'Financialization and the Firm’, in M. Dietrich and J. Krafft (eds), Handbook on the Economics and Theory of the Firm (Cheltenham: Elgar).

Barnes, T. (2004), ‘Culture: Economy’ in P. Cloke and R. Johnston (eds), Spaces of Geographical Thought Deconstructing Human Geography's Binaries (London/Thousand Islands/New Delhi: Sage publications), pp. 61-80.

Bayliss, K., Fine, B. and Robertson, M. (2013), 'From Financialisation to Consumption: the System of Provision Approach Applied to Housing and Water', FESSUD Working Paper Series, no 2. Available from: http://fessud.eu/wp-content/uploads/2013/04/FESSUDWorking-Paper-021.pdf [accessed 16 December 2015].

Bayliss, K. (2014), ‘The Financialisation of Water in England and Wales’ FESSUD Working Paper Series no 52. Available from: http://fessud.eu/wp-content/uploads/2013/04/52_Casestudy_The-Financialisation-of-Water-in-England-and-Wales_final_working-paper-521.pdf [accessed 16 December 2015].

Bayliss, K., Fine, B., Robertson, M. and Saad-Filho, A. (2015), ‘A Series of Thematic Country Synthesis Papers on Relevant Themes’, Leeds, UK: FESSUD project, (Deliverable D8.27).

Boyer, R. (2013), ‘The Present Crisis: A Trump for a Renewed Political Economy’, Review of Political Economy, 25 (1), pp. 1-38.

Brassett, J., Rethel, L. and Watson, M. (2010), 'The Political Economy of the Subprime Crisis: The Economics, Politics and Ethics of Response', New Political Economy, 15 (1), pp. $1-7$. 
This is the version of the article accepted for publication in New Political Economy published by Taylor \& Francis:

http://www.tandfonline.com/doi/full/10.1080/13563467.2017.1259304

Accepted version downloaded from SOAS Research Online: http://eprints.soas.ac.uk/23290/

Brown, W. (2015), Undoing the Demos: Neoliberalism's Stealth Revolution (Cambridge:

MIT Press).

Bryan, D. and Rafferty, M. (2014), 'Political Economy and Housing in the Twenty First Century - From Mobile Homes to Liquid Housing', Housing, Theory and Society 31 (4), pp. 404-412.

Christophers, B. (2013), Banking across Boundaries: Placing Finance in Capitalism (Chichester: Wiley-Blackwell).

Christophers, B. (2015a), ‘The Limits to Financialization’, Dialogues in Human Geography, 5 (2), pp. 183-200.

Christophers, B. (2015b), 'From Financialization to Finance: For 'De-Financialization’’, Dialogues in Human Geography, 5 (2), pp. 229-32.

Christopherson, S., Martin, R. and Pollard, J. (2013), ‘Financialisation: Roots and Repercussions’ Cambridge Journal of Regions, Economy and Society, 6 (3), pp. 351-357

Churchill, J. (2014), 'Towards a Framework for Understanding the Recent Evolution of Pension Systems in the European Union', FESSUD Working Paper Series, no 12. Available from: http://fessud.eu/wp-content/uploads/2013/04/Towards-a-framework-for-understandingthe-recent-evolution-of-pension-systems-in-the-European-Union-FESSUD-working-paper12.pdf [accessed 16 December 2015].

Cornwall, A. and Eade, D. (eds), (2010), Deconstructing Development Discourse: Buzzwords and Fuzzwords (Oxfam and Rugby: Practical Action Publishing).

Dodd, N. (1994), The Sociology of Money: Economics, Reason and Contemporary Society (Cambridge: Polity Press).

Dodd, N. (2016), The Social Life of Money (Princeton: Princeton University Press). Elson, D. (2014), 'Economic Crisis from the 1980s to the 2010s: A Gender Analysis', in S. Rai and G. Waylen (eds), New Frontiers in Feminist Political Economy (London: Routledge). 
This is the version of the article accepted for publication in New Political Economy published by Taylor \& Francis: http://www.tandfonline.com/doi/full/10.1080/13563467.2017.1259304

Accepted version downloaded from SOAS Research Online: http://eprints.soas.ac.uk/23290/

Engelen, E., R. Fernandez and R. Hendrikse (2014), 'How Finance Penetrates its Other: A Cautionary Tale on the Financialization of a Dutch University’, Antipode, 46 (4), pp. 10721091.

Epstein, G. (2005), 'Introduction’, in G. Epstein (ed.), Financialization and the World Economy (Cheltenham and Northampton: Edward Elgar).

Fine, B. (2002), The World of Consumption: The Cultural and Material Revisited (London: Routledge).

Fine, B. (2009a), 'The Economics of Identity and the Identity of Economics?', Cambridge Journal of Economics, 33 (2), pp. 175-91.

Fine, B. (2009b), 'Political Economy for the Rainbow Nation: Dividing the Spectrum?', prepared for 'Making Sense of Borders: Identity, Citizenship and Power in South Africa', South African Sociological Association, Annual Conference, June/July, Johannesburg. Available from: http://eprints.soas.ac.uk/7972/1/sasa_benfine.pdf [accessed 16 December 2015].

Fine, B. (2010), 'Locating Financialisation’, Historical Materialism, 18 (2), pp. 97-116. Fine, B. (2010), Theories of Social Capital: Researchers Behaving Badly (London: Pluto Press).

Fine, B. (2013), 'Consumption Matters’, Ephemera, 13 (2), pp. 217-48. Available from: http://www.ephemerajournal.org/contribution/consumption-matters [accessed 16 December 2015].

Fine, B. (2013), ‘Economics - Unfit for Purpose: The Director’s Cut', SOAS Department of Economics Working Paper Series, no 176. Available from:

http://www.soas.ac.uk/economics/research/workingpapers/file81476.pdf, [accessed 16 December 2015], revised and shortened to appear as, 'Economics: Unfit for Purpose’, Review of Social Economy, LXXI (3), 2013, pp. 373-89. 
This is the version of the article accepted for publication in New Political Economy published by Taylor \& Francis:

http://www.tandfonline.com/doi/full/10.1080/13563467.2017.1259304

Accepted version downloaded from SOAS Research Online: http://eprints.soas.ac.uk/23290/

Fine, B. (2014a), 'Financialization from a Marxist Perspective', International Journal of Political Economy, 42 (4), pp. 47-66.

Fine, B. (2014b), 'The Continuing Enigmas of Social Policy', prepared for the UNRISD project on Towards Universal Social Security in Emerging Economies, UNRISD Working Paper 2014-10. Available from: http://www.unrisd.org/Fine [accessed 16 December 2015]. Fine, B. (2016), 'From Performativity to the Material Culture of Legal Expertise?', London Review of International Law, forthcoming.

Fine, B. and Leopold, E. (1990), ‘Consumerism and the Industrial Revolution’, Social History, 15 (2), pp. 151-79.

Fine, B. and Saad Filho, A. (2016), 'Thirteen Things You Need to Know about Neoliberalism', Critical Sociology, forthcoming.

Froud, J., Leaver, A. and Williams, K. (2007), 'New Actors in a Financialised Economy and the Remaking of Capitalism', New Political Economy, 12 (3), pp. 339-347.

Froud, J., Johal, S. and Williams, K. (2002), 'Financialisation and the Coupon Pool’, Capital and Class, 78 (9), pp. 119-51.

Graeber, D. (2014), 'Anthropology and the Rise of the Professional-Managerial Class', Journal of Ethnographic Theory, 4 (3), pp.73-88.

Graves-Brown, P. (2000), 'Introduction’ in P. Graves-Brown (ed.), Matter, Materiality and Modern Culture (London: Routledge), pp. 1-9.

Gronow, J. (1997), The Sociology of Taste (London: Routledge).

Haiven, M. (2014), Cultures of Financialization: Fictitious Capital in Popular Culture and Everyday Life (Basingstoke: Palgrave MacMillan).

Jessop, B. (2015), 'Hard Cash, Easy Credit, Fictitious Capital: Critical Reflections on Money as a Fetishised Social Relation', Finance and Society 1 (1), pp. 20-37. 
This is the version of the article accepted for publication in New Political Economy published by Taylor \& Francis:

http://www.tandfonline.com/doi/full/10.1080/13563467.2017.1259304

Accepted version downloaded from SOAS Research Online: http://eprints.soas.ac.uk/23290/

Jessop, B. and Sum, N. (2001), 'Pre-disciplinary and Post-disciplinary Perspectives’ New

Political Economy, 6 (1), pp. 89-101.

Johal, S., Moran, M. and Williams, K. (2014), 'Power, Politics and the City of London after the Great Financial Crisis', Government and Opposition, 49 (3), pp. 400-25.

Karacimen, E. (2014), 'Dynamics behind the Rise in Household Debt in Advanced Capitalist

Countries: An Overview’, FESSUD Working Paper Series, no. 9. Available from:

http://fessud.eu/wp-content/uploads/2013/04/Dynamics-behind-the-Rise-in-Household-Debt-

FESSUD-Working-Paper-09-1.pdf [accessed 16 December 2015].

Krippner, G. R. (2005), 'The Financialization of the American Economy’ Socio-Economic

Review, 3 (2), pp. 173-208.

Langley, P. (2008), The Everyday Life of Global Finance (Oxford: Oxford University Press).

Lapavitsas, C. (2013), Profiting without Producing: How Finance Exploits Us All (London:

Verso).

Lawson, T. (2016), 'Social Positioning and the Nature of Money', Cambridge Journal of Economics, forthcoming.

Leyshon, A. and Thrift, N. (2007), 'The Capitalization of Almost Everything: The Future of Finance and Capitalism', Theory, Culture \& Society, 24 (7-8), pp. 97-115.

Marron, D. (2013), 'Governing Poverty in a Neoliberal Age: New Labour and the Case of

Financial Exclusion', New Political Economy, 18 (6), pp. 785-810.

Martin, R. (2002), Financialization of Daily Life: Labor in Crisis (Philadelphia: Temple University Press).

Martin, R. (2011), Under New Management: Universities, Administrative Labor, and the Professional Turn (Philadelphia: Temple University Press).

Michell, J. and Toporowski, J. (2014), 'Critical Observations on Financialization and the Financial Process', International Journal of Political Economy, 42 (4), pp. 67-82. 
This is the version of the article accepted for publication in New Political Economy published by Taylor \& Francis:

http://www.tandfonline.com/doi/full/10.1080/13563467.2017.1259304

Accepted version downloaded from SOAS Research Online: http://eprints.soas.ac.uk/23290/

Montgomerie, J. (2009), ‘The Pursuit of (Past) Happiness? Middleclass Indebtedness and

American Financialisation', New Political Economy, 14 (1), pp. 1-24.

Morrish, H. and Sauntson, L. (2013), 'Business-Facing Motors for Economic Development:

An Appraisal Analysis of Visions and Values in the Marketised UK University', Critical

Discourse Studies, 10 (1), pp. 61-80.

Peet, R. (2000), 'Culture, Imagery and Rationality in Regional Economic Development', Environment and Planning A, 32 (7), pp. 1215-34.

Pike, A. and Pollard, J. (2010), ‘Economic Geographies of Financialization’, Economic

Geography, 86 (1), pp. 29-51.

Poovey, M. (2015), ‘On ‘the Limits to Financialization’, Dialogues in Human Geography, 5 (2), pp. 220-24.

Robertson, M. (2014), ‘Case Study: Finance and Housing Provision in Britain', FESSUD Working Paper no. 51. Available from: http://fessud.eu/wp-content/uploads/2013/04/CaseStudy_-Finance-and-Housing-Provision-in-Britain-working-paper-51.pdf $\quad$ [accessed 16 December 2015].

Santos, A. and Teles, N. (2014), ‘Recent Trends in Household Financial Behaviour’ in A. Santos and B. Fine (eds), 'Empirical Report on Cross-National Comparative Analysis of Household Financial Behaviour: Recent Trends', Leeds, UK: FESSUD project, (Deliverable D5.03).

Santos, A., Teles, N., Matias, R., Brown, A. and Spencer, D. (2013), ‘Empirical Report on Cross-National Comparative Analysis of Household Well-Being: Micro Analysis', Leeds, UK: FESSUD project, (Deliverable D5.04).

Saritas, S. (2013), 'Review of the Pension Provisions in the European Union Countries', Fessud Working Paper Series, no 13. Available from: http://fessud.eu/wp- 
This is the version of the article accepted for publication in New Political Economy published by Taylor \& Francis:

http://www.tandfonline.com/doi/full/10.1080/13563467.2017.1259304

Accepted version downloaded from SOAS Research Online: http://eprints.soas.ac.uk/23290/

content/uploads/2013/04/REVIEW-OF-THE-PENSION-PROVISION-ACROSS-THE-

EUROPEAN-UNION-COUNTRIES_13.pdf [accessed 16 December 2015].

Sawyer. M. (2014), 'What Is Financialization?’, International Journal of Political Economy, 42 (4), pp. 5-18.

Seabrooke, L. (2010), 'What Do I Get? The Everyday Politics of Expectations and the Subprime Crisis’, New Political Economy, 15 (1), pp. 51-70.

Scheiring, G. (2016), 'Sustaining Democracy in the Era of Dependent Financialization: Karl Polanyi's Perspectives on the Politics of Finance', Intersections. East European Journal of Society and Politics, 2 (2), pp. 84-103. Stanley, L. (2014), “"We're Reaping What We Sowed”: Everyday Crisis Narratives and Acquiescence to the Age of Austerity’, New Political Economy, 19 (6), pp. 895-917.

Vitali, S., Glattfelder, J. and Battiston, S. (2011), 'The Network of Global Corporate Control'. Available from: http://arxiv.org/pdf/1107.5728v2.pdf [accessed 16 December 2015]. 